\title{
Pensonomonoor
}

2014, vol. 72, 113-123

http://dx.doi.org/10.12657/denbio.072.010

Katarzyna Marcysiak

\section{Geographical differentiation of Dryas octopetala in Europe based on morphological features}

\author{
Received: 10 October 2013; Accepted: 20 May 2014
}

\begin{abstract}
Dryas octopetala is an important arctic alpine species, but its morphological analyses are scarce. The study deals with present European biogeographical structure based on morphology and its relations to the phylogenetic structure and the climate. Characters of leaves from 23 isolated populations were measured, statistically characterized and analyzed with the use of ANOVA and the discriminant analysis. All the features differentiated the tested samples significantly. Differences between plants representing regions were greater than between the samples within regions with regard to the four characters. The most visible division ran between the samples coming from the southern and the northern parts of the range, with the sample from the Western Scandinavia occupying the central position. Correlations between characters and climactic factors were shown, and the size of the leaf was associated mainly with the minimum temperatures of spring months, while the leaf shape with the rainfall during the summer months. Characters differentiating the regions and discriminating populations strongly were mostly dependent on the influence of the climate. The results of the present study were not fully consistent with the outcomes of the biogeographic molecular analyses of the researched species. Some parallels can be drawn when comparing the present analyses with the geographic differentiation of two other arctic-alpine shrubs Salix herbacea and $S$. reticulata. Although morphological diversity of Dryas octopetala showed a geographic structure, it was most probably shaped mainly by the influence of the environmental and climatic factors.
\end{abstract}

Additional key words: arctic-alpine species, biogeography, biometrics, climatic conditions, statistical analyses

Address: K. Marcysiak, Kazimierz Wielki University, Botany Department, al. Ossolinskich 12, 85-093 Bydgoszcz, Poland, e-mail: marc@ukw.edu.pl

\section{Introduction}

Dryas octopetala is one of quite numerous arctic-alpine species (Zając and Zając 2009). In Europe, the species with this type of distribution occur in the north of the continent, in the Arctic, and in the mountains of the Alpine system. This disjunction is the result of successive contractions and expansions of plant ranges, often called plant migrations, which were forced by climate fluctuations in the Pleistocene and the early Holocene (Comes and Kadereit 1998; Hewitt 1999; Birks and Willis 2008). The migrations were accompanied by processes that contributed to the diversity and the internal variability of parts of ranges and individual populations (Jones and Gliddon 1999; Abbott and Brochmann 2003; Kapralov et al. 2006; Birks 2008; Birks and Willis 2008). Recently, popular studies of arctic-alpine species, aiming to 
investigate their internal differentiation and variability at the molecular level, allow also to trace the changes of plant ranges, and conclude what were the Pleistocene refuges and migration routes of species.

Attempts to explore the diversity of arctic-alpine species with morphological markers are few. Although for many years research, including taxonomic studies, has been based on morphological characteristics, recently they have attracted less confidence, especially in the study of variation within the lower level taxa, due to the possible effects of environmental factors on this variability. In particular, there are few studies comprising large parts of plant ranges. The morphological variation of the European ranges of Salix herbacea and S. reticulata arctic-alpine dwarf shrubs was recently characterized by Marcysiak (2012 a,b), who obtained a geographical structure only partially in accordance with the postglacial history of the species and showed the relationship of features of $S$. herbacea leaves with the climate.

Still, congruency of results of molecular and morphological analyses was found in several studies of variation within species or between closely related species of gymnosperms (Douaihy et al., 2012; Boratyński et al., 2013; Jasińska et al., 2013).

Dryas octopetala, an essential component of the Pleistocene tundra, is also one of the most important species of contemporary communities occurring at high latitudes of the northern hemisphere. In Europe, we can also find it in the calcareous mountains, usually above the subalpine zone. Dryas octopetala reproduces both generatively and clonally, which is typical for plants of cold climates, and individuals can reach the maximum age of 500 years, but populations are predominated by young genets. Such a structure of the population enables the species to adapt to changing environmental conditions and persist in them (de Witte et al. 2012). Although seeds of Dryas octopetala are adapted for long-distance wind dispersal, the rates of seedling establishment are low which limits the flow of new genotypes into populations. The species also show a strong local adaptation which is manifested by the elimination of transplanted ecotypes in a foreign environment (Bennington et al. 2012). Thus the differences between isolated populations of the species may persist for a long time. However, it is widely accepted and proven that the morphology of the plant can be influenced by environmental conditions (Bazzaz et al. 1987; Mal and Lovett-Doust 2005).

Dryas octopetala has already been the subject of various studies (McGraw and Antonovics 1983; Rieley et al. 1995; Vasari 1999; Šibik et al. 2004). Some of them have focused on the genetic variability of the species, the possibility of crossing with $D$. integrifolia, its postglacial migration and possible refugia (Philipp and Siegismund 2003; Vik et al. 2010). Skrede et al. (2006), in her research on molecular differentiation of Dryas octopetala sensu lato within the whole circumpolar range found that the populations of the species

Table 1. Collection data of Dryas octopetala samples

\begin{tabular}{|c|c|c|c|c|c|c|c|}
\hline Acronym & Location & Region & $\begin{array}{c}\text { No. of } \\
\text { individuals }\end{array}$ & $\begin{array}{l}\text { No. of } \\
\text { leaves }\end{array}$ & alt. & $\mathrm{N}$ & $\mathrm{E}$ \\
\hline ES & Norway, Finnmark, Nordkapp & Eastern Scandinavia & 30 & 300 & 100 & 71.0893 & 25.7840 \\
\hline WS & Norway, Hardangevidda & Western Scandinavia & 30 & 298 & 1300 & 60.5593 & 08.0792 \\
\hline EC1 & Romania, Piatra Craiului, Șaua Grindului & & 33 & 310 & 2206 & 45.525 & 25.2086 \\
\hline EC2 & Romania, Muntii Rodnei & Eastern Carpathians & 33 & 320 & 1910 & 47.5383 & 24.8587 \\
\hline $\mathrm{SC} 1$ & Romania, Parâng Mts. & Southern Carpa- & 31 & 282 & 2390 & 45.3540 & 23.5268 \\
\hline SC2 & Romania, Muntii Retezat & thians & 15 & 111 & 2210 & 45.3567 & 22.9172 \\
\hline $\mathrm{NC} 1$ & Polska, Małe Pieniny & & 16 & 160 & 715 & 49.4017 & 20.5712 \\
\hline NC2 & Slovakia, Belanské Tatry & & 20 & 157 & 1615 & 49.2503 & 20.2032 \\
\hline NC3 & Slovakia, Nizke Tatry & & 29 & 241 & 1750 & 48.9808 & 19.6297 \\
\hline NC4 & Poland, Tatra Mts., Wielka Kopa Królowa & Western Carpathians & 26 & 260 & 1530 & 49.2645 & 20.0030 \\
\hline NC5 & Poland, Tatra Mts., Sarnia Skała & & 30 & 300 & 1377 & 49.2762 & 19.9578 \\
\hline NC6 & Poland, Tatra Mts., Czerwone Wierchy & & 30 & 300 & 1750 & 49.2533 & 19.9018 \\
\hline Alp1 & Italy, Dolomites, Monte Cristallo & & 27 & 270 & 2167 & 46.5691 & 12.1839 \\
\hline Alp2 & Austria, Grubigstein, top, meadow & Alps & 29 & 290 & 2207 & 47.3831 & 10.8411 \\
\hline Alp3 & Austria, Grubigstein, steep slope, on loose rocks & & 30 & 300 & 2166 & 47.3832 & 10.8439 \\
\hline StPla & $\begin{array}{c}\text { Bulgaria, Centralna Stara Planina mountains, } \\
\text { Kozia Stena reserve }\end{array}$ & & 31 & 307 & 1660 & 42.7843 & 24.5350 \\
\hline Ril & Bulgaria, Rila mountains, Sedemte Ezera valley & & 32 & 290 & 2425 & 42.1898 & 23.3238 \\
\hline SPla & Macedonia, Šar-Planina mountains & Balkans & 30 & 300 & 2010 & 42.0243 & 20.8578 \\
\hline SuPla & Serbia, Suva Planina & & 25 & 250 & 1680 & 43.1815 & 22.1587 \\
\hline Din1 & Montenegro, Dinaric Mountains, Durmitor & & 25 & 250 & 2120 & 43.1215 & 19.0325 \\
\hline Din2 & Montenegro, Dinaric Mountains, Komovi & & 27 & 270 & 1900 & 42.6883 & 19.6745 \\
\hline Ap & Italy, Apuan Alps & Appenines & 27 & 270 & 1600 & 44.10 & 10.1333 \\
\hline Pyr & Andorra, Pico de Casamanya & Pyrenees & 30 & 300 & 2670 & 42.5812 & 01.5713 \\
\hline
\end{tabular}




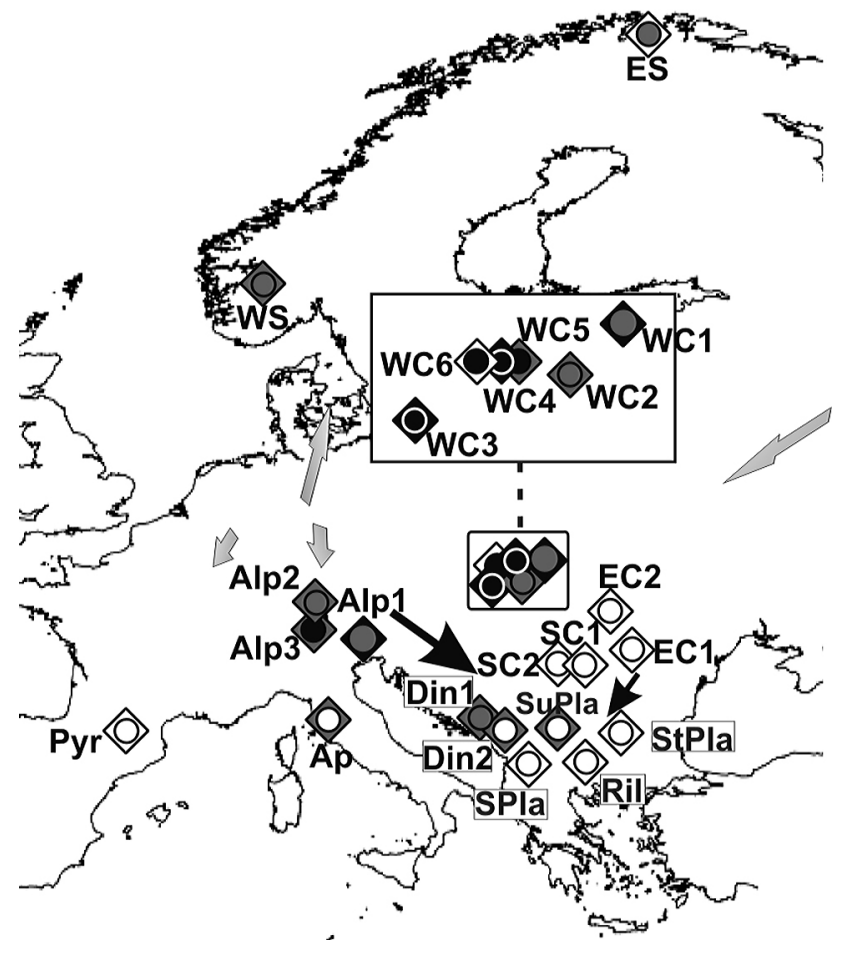

Fig. 1. Location and selected characteristics of Dryas octopetala samples, compared to the previously proposed migration routes of the species; squares - mean $b l / b l w$ values: $1.65<$ white $<1.82,1.82<$ grey $<2.00,2.00<$ black $<2.36$; circles - mean blw/aw values: $2.57<$ black $<3.00$, $3.00<$ grey $<4.08,4.08<$ white $<5.13$; arrows - migration routes based on molecular studies by: light grey Skrede et al. 2006, black - Ronikier unpubl. preliminary analysis; characters acronyms as in Table 2

in the Alps and Western Scandinavia originated from the glacier foreland on the European lowland, while the populations in the Carpathians and Eastern Scandinavia came from the Northern Siberia. Recently Ronikier and Cieślak (2012) described three distinct AFLP lineages of the species across Europe and concluded that present Balkan range emerge from the last glacial migration from the Carpathians and the Alps.

Morphological characters of Dryas octopetala have rarely been used in research. Several features of the leaves were used by Philipp and Siegismund (2003), who analyzed the hybrid zone between $D$. octopetala and D. integrifolia in Greenland. The parallel analysis of isoenzymes carried out by the authors gave results not fully complying with the grouping based on morphology.

In the present paper, I characterize the morphological variation and differentiation between populations of Dryas octopetala, coming from different parts of the range in Europe. I expected that the morphological differences may occur between isolated mountain ranges and populations within them, and their clustering may reflect the existing biogeographic divisions. I want to verify whether the biogeographical structure based on the leaf morphology is similar to that obtained in the molecular studies by Skrede et al. (2006) and Ronikier and Cieślak (2012). I also try to check if Dryas morphology depended on the climate, and if some parallels between morphological differentiation of Dryas octopetala and other arctic-alpine species, investigated by Marcysiak (2012 a, b), could be observed.

\section{Materials and methods \\ Collection of material and measuring}

The research material consisted of leaves of Dryas octopetala from Eastern and Western Scandinavia, the Western, Eastern and Southern Carpathians, the Central Alps, the Appenines, the Pyrenees and the Balkans (Fig. 1, Table 1). From each of the 23 population, depending on its size, the leaves were collected from (15) 20-30 distinguishing individuals, spaced out at least $3 \mathrm{~m}$, to avoid the collection of one genet. From each individual, from the central part of the stem of at least 5 different shoots, about 10 leaves were collected, without any visible infection or damage. After collection, the leaves were dried and herbarized. The herbarium is deposited at the Department of Botany of Kazimierz Wielki University in Bydgoszcz.

The herbarized material was measured. As a small portion of the leaves was damaged during transport and drying, ultimately, there were 6136 leaves of 637 individuals measured in total. (Table 1). The leaves of each individual were scanned and measured automatically with the use of digiShape software (CortexNova); additionally, the teeth were counted. The measured characteristics were used as the basis for calculating the synthetic ones, which describe the leaf shape. Typical features used in the morphological analyses of leaves were chosen (Philipp and Siegismund 2003; Boratyński et al. 2008; Marcysiak 2012 c). In general, the leaves were characterized on the basis of nine measured/counted characteristics and 5 proportions (Fig. 2, Table 2).

\section{Analyses}

Before starting the analyses, the normality of distribution of characters was examined with K-S and Lilliefors test.

Descriptive statistics were provided for the entire data set, for each region and sample. The variability of characters in each sample, region and the entire set of data was tested using the variation coefficient $(\mathrm{Cv}=\mathrm{M} / \mathrm{SD} \times 100)$. For comparisons of the variability between samples and regions, arithmetic means of variation coefficients of characters in populations were used (Soulé and Zegers 1996). In the entire data set, mutual correlations of characters were examined using Pearson's correlation coefficient. 
Table 2. Characters of Dryas octopetala leaves, their descriptive statistics, correlations and importance in the differentiation of populations and regions

\begin{tabular}{|c|c|c|c|c|c|c|c|c|c|}
\hline \multirow{2}{*}{ Character } & \multirow{2}{*}{ Acronym } & \multirow{2}{*}{$\begin{array}{l}\text { Aryth- } \\
\text { metic } \\
\text { mean }\end{array}$} & \multirow{2}{*}{ Min } & \multirow{2}{*}{ Max } & \multirow{2}{*}{$\mathrm{Cv}$} & \multicolumn{2}{|c|}{$\begin{array}{l}\text { Characters } \\
\text { correlated at } \\
p>0.01 \text { with }\end{array}$} & \multirow{2}{*}{$\begin{array}{l}\text { Characters } \\
\text { diversifying } \\
\text { regions* }\end{array}$} & \multirow{2}{*}{$\begin{array}{c}\text { Discrimination } \\
\text { power testing } \\
\text { among populations } \\
\text { partial Wilk's } \lambda \\
\mathrm{p}<0.001\end{array}$} \\
\hline & & & & & & $\begin{array}{l}\text { tem- } \\
\text { pera- } \\
\text { ture }\end{array}$ & $\begin{array}{l}\text { preci- } \\
\text { pita- } \\
\text { tion }\end{array}$ & & \\
\hline Perimeter of a leaf blade $[\mathrm{mm}]$ & per & 39.59 & 13.59 & 110.01 & 30.85 & & & & 0.777 \\
\hline Area of a leaf blade $[\mathrm{mm}]$ & ar & 67.10 & 8.70 & 381.44 & 56.21 & $\times$ & & & 0.848 \\
\hline Length of a leaf blade [mm] & $\mathrm{bl}$ & 12.51 & 4.10 & 34.52 & 29.67 & $x$ & & & 0.850 \\
\hline Maximum width of a leaf blade [mm] & blw & 3.34 & 1.11 & 8.00 & 27.61 & & & & 0.830 \\
\hline Width of a leaf base $[\mathrm{mm}]$ & bw & 4.57 & 0.89 & 11.35 & 30.61 & & & & 0.913 \\
\hline $\begin{array}{l}\text { Maximal width of an apical tooth } \\
\text { [mm] }\end{array}$ & aw & 1.75 & 0.35 & 5.88 & 36.42 & $\times$ & & $\times$ & 0.668 \\
\hline Length of a biggest tooth [mm] & $\mathrm{tl}$ & 2.24 & 0.81 & 5.30 & 26.11 & $x$ & & & 0.722 \\
\hline Length of a petiole $[\mathrm{mm}]$ & $\mathrm{pl}$ & 16.02 & 4.19 & 47.46 & 33.84 & & & & 0.880 \\
\hline Number of teeth on a leaf blade margin & tn & 14.20 & 6.00 & 27.00 & 17.06 & & $x$ & $\times$ & 0.769 \\
\hline Ratio of area/perimeter (char. 2/char. 1) & ar/per & 1.59 & 0.58 & 3.76 & 25.73 & $\times$ & & & 0.829 \\
\hline $\begin{array}{l}\text { Ratio of leaf length/max. width } \times 2 \\
(\text { char. } 3 /(\text { char. } 4 \times 2))\end{array}$ & $\mathrm{bl} / \mathrm{blw}$ & 1.89 & 0.97 & 4.43 & 18.99 & & & & 0.832 \\
\hline $\begin{array}{l}\text { Ratio of max. width } \times 2 / \text { width of leaf } \\
\text { base (char. } 4 \times 2 / \text { char.5) }\end{array}$ & $\mathrm{blw} / \mathrm{bw}$ & 1.51 & 0.44 & 4.29 & 22.42 & & $\times$ & & 0.871 \\
\hline $\begin{array}{l}\text { Ratio of max. width } \times 2 / \text { width of } \\
\text { apical tooth (char. } 4 \times 2 / \text { char. } 6)\end{array}$ & blw/aw & 4.20 & 1.26 & 25.36 & 39.15 & $\times$ & $\times$ & $\times$ & 0.776 \\
\hline $\begin{array}{l}\text { Ratio of petiole length/sum of blade } \\
\text { and petiole length (character 11/ } \\
\text { (char. } 3 \text { + char.11)) }\end{array}$ & $\mathrm{pl} / \mathrm{pbl}$ & 0.56 & 0.29 & 0.72 & 10.46 & & & $\times$ & 0.889 \\
\hline
\end{tabular}

${ }^{*}$ results of nested variance analysis; variance greater between regions than between samples within regions at $\mathrm{p}<0.05$

Differentiation between samples and regions was examined with the help of univariate analysis of variance (ANOVA / ANCOVA). To determine which features differentiated between populations, the posthoc procedure with the use of the RIR Tukey test for unequal frequencies were conducted. The results were illustrated by means of box-and-whiskers plots. The significance of the variation between regions and between samples within regions was determined with the nested variance analysis (Sokal and Rohlf 2003).

Multivariate relationships between populations and discrimination power of chosen characters were tested using stepwise discrimination analysis. Only shape characters were selected for this analysis, as mutual correlations between them were weaker and less frequent, compared to the size characters. The position of the populations along the first two discriminant variables were examined and presented on the scatterplot (Sokal and Rohlf 2003; Tabachnik and Fidell 2007).

The connections of Dryas octopetala features to the altitude and the bioclimatic factors were checked using Spearman's $r$ coefficient for non-parametric distributions. The data concerning the bioclimatic factors were obtained from publicly available databases WorldClim; 'Data for current conditions (1950-2000)' and highest resolution 30 arc-seconds were used (Hijmans et al. 2005).
Calculations and analyzes were performed using software STATISTICA (StatSoft), with the exception of the nested variance analyses that was performed by means of the JMP software.

\section{Results}

The distribution of values of analyzed characters were unimodal or very close to unimodal.

The mean coefficient of variation of characters was almost $29 \%$, and ranged from about $10 \%$ for $\mathrm{pl} / \mathrm{pbl}$ to over $56 \%$ of leaf area (ar) (Table 2). The mean coefficient of individual samples ranged from less than $15 \%$ for $\mathrm{WC} 1$ to over $21 \%$ for the SuPla. In general, higher values of $\mathrm{Cv}$ were observed in samples from the Balkans, the Low and the High Tatras in the Western Carpathians and in Eastern Scandinavia.

Most features of Dryas octopetala showed significant correlations at $\mathrm{p}<0.01$. The highest values of correlation coefficients were found between the measured features; the synthetic features were tied together less frequently, and the correlations were weaker (not shown).

All the features differentiated significantly the tested samples at $\mathrm{p}<0.01$, whereas, Tukey's test showed similarities between some of the samples in terms of certain characters. As far as size characters were concerned, two population groups were appar- 


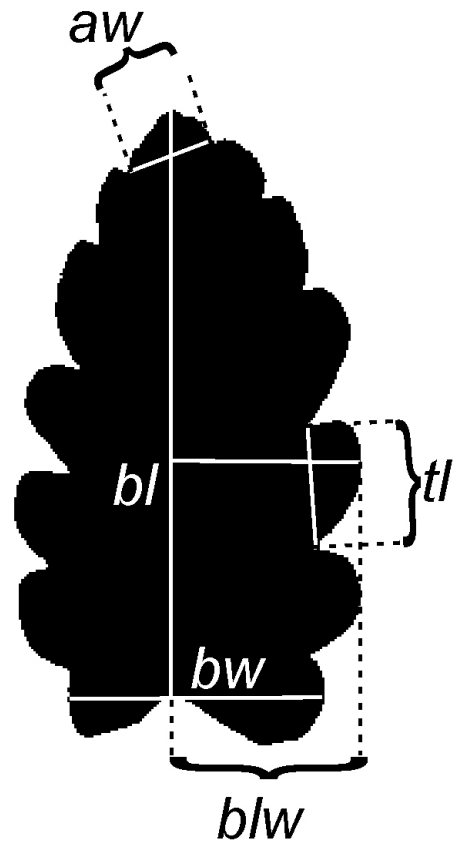

Fig. 2. Way of measuring the characteristics of Dryas octopetala leaf: bl - length of a leaf blade; blw - maximum width of a leaf blade; bw - width of a leaf base; aw maximal width of an apical tooth; tl - length of a biggest tooth

ently distinct: one of the smallest leaves - Alp3, ES SC1-2, and one of the largest leaves: Ap, NC2, Din2, SuPla and StPla, while other samples achieved intermediate values. In case of aw character, the samples grouped in differently: the leaves from the Western Carpathians (NC2-6) had the widest apex (aw), while those from the Southern and Eastern Carpathians, the Pyrenees, the Rila Mountains, the Šar-Plani- na Mountains and Eastern Scandinavia (SC1-2, EC12, Pyr, Ril, SPla, ES), the narrowest (App. 1). The shape characters differed populations somewhat less distinctly. The groups with the biggest and smallest character values, as in the case of size characters, can be found for the character ar/per. The leaves from the Western Carpathians (except NC6) and the Dolomites (Alp1) were more elongated (greater value of $b l / b l w)$ than in the rest of samples. The proportion of the petiole length in the whole leaf length $(\mathrm{pl} / \mathrm{pbl})$ reached the highest values in WS and the lowest in Ap and did not seem to show any regularity. Character $b l w / b w$ describes the shape of the lower half of the leaf: its lower values (tending to 1) mean almost linear leaf, and leaves of this shape were found in the Tatras and Alps (NC4-5, Alps1-3). Values of the ratio of the maximum leaf width to the width of leaf apex (blw/aw) divided samples into two groups: the northern group, comprising samples from the Scandinavia (ES, WS), Western Carpathians (NC1-6) and Alps (Alp1-3), and the southern group with the rest of the samples. In the northern group, leaves generally had wider apical tooth (aw) and the difference between the leaf width and aw was smaller (lower values of blw/aw). The wide apex tapered quite sharply and as a result, the very top of the leaf was more acute compared to the leaves of the southern groups. The leafs of the southern group usually had narrow and small apices somewhat hidden between the teeth below, so the top of the leaf was usually rounded. The division into northern and southern group is also evident in character $t n$, though not so distinctly, and the leaves from the north had fewer teeth than those from the south (App. 2).

Table 3. Results of the nested variance analysis of the Dryas octopetala leaf characters

\begin{tabular}{|c|c|c|c|c|c|c|c|}
\hline Character & Component & $\%$ & SS & MS & $\mathrm{df}$ & $\mathrm{F}$ & Prob $>$ F \\
\hline \multirow{5}{*}{ aw } & between regions & 21.371 & 497.224 & 49.7224 & 10 & 6.0356 & $0.0034^{*}$ \\
\hline & between populations in regions & 6.890 & 82.6862 & 7.51692 & 11 & 9.1518 & $<.0001^{*}$ \\
\hline & within population & 16.240 & 498.826 & 0.85856 & 581 & 3.8304 & $<.0001^{*}$ \\
\hline & Residual & 55.499 & & & & & \\
\hline & Total & 100 & & & & & \\
\hline \multirow{5}{*}{$t n$} & between regions & 16.543 & 7197.99 & 719.799 & 10 & 3.0362 & $0.0417^{*}$ \\
\hline & between populations in regions & 13.679 & 2372.59 & 215.69 & 11 & 13.6033 & $<.0001^{*}$ \\
\hline & within population & 23.612 & 9684.66 & 16.6689 & 581 & 5.9471 & $<.0001^{*}$ \\
\hline & Residual & 46.166 & & & & & \\
\hline & Total & 100 & & & & & \\
\hline \multirow{5}{*}{ blw/aw } & between regions & 27.288 & 3924.35 & 392.435 & 10 & 10.8809 & $0.0003^{*}$ \\
\hline & between populations in regions & 4.476 & 362.251 & 32.9319 & 11 & 8.9712 & $<.0001^{*}$ \\
\hline & within population & 8.249 & 2206.64 & 3.79801 & 581 & 2.3302 & $<.0001^{*}$ \\
\hline & Residual & 59.987 & & & & & \\
\hline & Total & 100 & & & & & \\
\hline \multirow{5}{*}{$p l / p b l$} & between regions & 13.135 & 2.60577 & 0.26058 & 10 & 6.4049 & $0.0029 *$ \\
\hline & between populations in regions & 3.243 & 0.41328 & 0.03757 & 11 & 3.6171 & $<.0001^{*}$ \\
\hline & within population & 26.473 & 6.33874 & 0.01091 & 581 & 5.4807 & $<.0001^{*}$ \\
\hline & Residual & 57.149 & & & & & \\
\hline & Total & 100 & & & & & \\
\hline
\end{tabular}


Table 4. Spearman's rank correlation coefficient between bioclimatic factors and characters of Dryas octopetala; only factors and characters expressing significant correlations at $\mathrm{p}<0.01$ (numbers in bold) are shown

\begin{tabular}{llllrrrrrr}
\hline & $a r$ & $b l$ & $b w$ & \multicolumn{1}{c}{$t l$} & $a w$ & $b l w / b w$ & $b l w / a w$ & tn & $a r / p e r$ \\
\hline tmin3 & 0.38 & 0.46 & 0.53 & 0.42 & 0.30 & -0.13 & 0.18 & 0.14 & 0.55 \\
tmin4 & 0.59 & 0.58 & 0.59 & 0.48 & 0.40 & 0.02 & 0.13 & 0.18 & 0.67 \\
tmin5 & 0.60 & 0.58 & 0.61 & 0.48 & 0.39 & 0.04 & 0.16 & 0.19 & 0.69 \\
tmin6 & 0.59 & 0.56 & 0.57 & 0.44 & 0.35 & 0.08 & 0.18 & 0.23 & 0.66 \\
tmin7 & 0.46 & 0.42 & 0.50 & 0.36 & 0.22 & 0.11 & 0.25 & 0.23 & 0.56 \\
tmin8 & 0.43 & 0.37 & 0.48 & 0.28 & 0.14 & 0.09 & 0.32 & 0.26 & 0.53 \\
tmax6 & 0.48 & 0.51 & 0.46 & 0.34 & 0.20 & 0.01 & 0.27 & 0.31 & 0.53 \\
tmax8 & 0.34 & 0.34 & 0.34 & 0.17 & -0.11 & 0.28 & 0.54 & 0.53 & 0.37 \\
prec6 & -0.06 & -0.07 & -0.06 & 0.00 & 0.34 & -0.33 & -0.56 & -0.54 & 0.00 \\
prec7 & -0.08 & -0.02 & -0.04 & 0.09 & 0.48 & -0.54 & -0.70 & -0.66 & 0.01 \\
prec8 & -0.03 & 0.02 & 0.02 & 0.15 & 0.55 & -0.54 & -0.74 & -0.70 & 0.05 \\
prec9 & 0.10 & 0.12 & 0.20 & 0.28 & 0.57 & -0.43 & -0.59 & -0.53 & 0.16 \\
MTWeQ & 0.35 & 0.48 & 0.36 & 0.53 & 0.60 & -0.34 & -0.37 & -0.30 & 0.49 \\
MTDQ & 0.03 & 0.01 & 0.13 & -0.12 & -0.41 & 0.38 & 0.66 & 0.51 & 0.08 \\
AP & 0.03 & 0.02 & 0.12 & 0.12 & 0.47 & -0.33 & -0.54 & -0.50 & 0.11 \\
PWeQ & -0.08 & -0.06 & -0.05 & 0.02 & 0.43 & -0.40 & -0.66 & -0.65 & 0.00 \\
PWaQ & -0.07 & -0.03 & -0.05 & 0.07 & 0.48 & -0.48 & -0.71 & -0.67 & 0.01 \\
\hline
\end{tabular}

in months: tmin - minimum temperature, tmax - maximum temperature, prec - precipitation; MTWeQ - Mean Temperature of Wettest Quarter; MTDQ - Mean Temperature of Driest Quarter; AP - Annual Precipitation; PWeQ - Precipitation of Wettest Quarter; PWaQ Precipitation of Warmest Quarter

The nested variance analysis showed that differences between plants representing regions were greater than between the samples within regions with regard to only four characters. The variance within populations was generally high, but the residual variation reached the highest level, indicating the great differences between leaves in individuals and populations (Table 3 ).

All the characters significantly discriminated the analyzed samples, although their discriminatory power was not big, the biggest for characters aw, $t l$ and $t n$ (Table 2). The first two discriminatory variables explained nearly $75 \%$ of the total variance. The

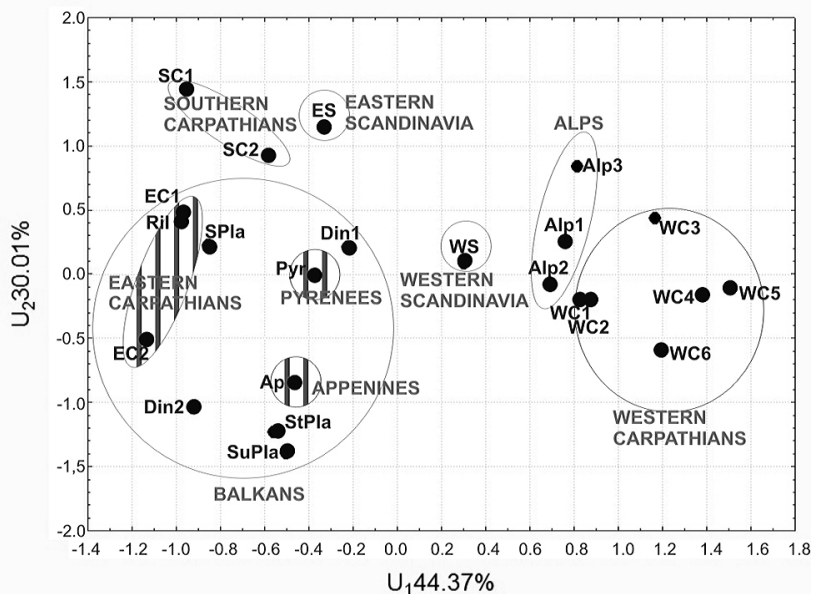

Fig. 3. Results of discrimination analysis for Dryas octopetala on the plot of two first discrimination variables; black points - samples means; black letters - samples acronyms as in Table 1; areas surrounded by grey lines - samples belonging to one region, striped areas - overlapping regions; grey letters - regions name grouping split the samples into two parts, the first comprising samples from the Alps and the Western Carpathians and the second, containing all samples from the southern parts of the species range and Eastern Scandinavia. The sample from the Western Scandinavia occupied the central position. Variable $\mathrm{U}_{1}$ was correlated with features blw/aw, aw and $t n$ most strongly (Fig. 3).

The correlations of Dryas octopetala characters with the climactic factors were shown by some characters of size and shape, and the size of the leaf ( $a r, b l$ and $b w$ ) was associated mainly with the minimum temperatures of the spring months (positive correlation), while the leaf shape ( $a r, b l$ and $b w$ ) with the rainfall during the summer months (negative correlation). As a result, leaves from the more rainy regions had fewer teeth and were more linear, but with an acute apex. The exception was character ar/per, dependent on the temperature of the spring and the summer, which means that leaves were more indented in the regions with lower temperatures. All correlations were moderate (Table 4). The correlations with altitude were found only for the Balkan samples, significant at $\mathrm{p}<0.05$ for: $a r, b w, t l, p l$ and ar/per.

\section{Discussion}

\section{Biogeographic structure of Dryas octopetala based on leaf morphology}

On the basis of the results of this study one can conclude that Dryas octopetala populations differed in terms of leaf morphology and this diversity showed a 
geographic structure. Grouping of the samples and regions in the present work confirmed the biogeographic and phylogeographic patterns reported for other arctic-alpine species. The clustering of the Carpathian samples was congruent with the biogeographic division of the massif to the western, southern and eastern parts (Ronikier 2011). A discrepancy between the samples from western and eastern Scandinavia, found in the present analyses, has been observed long also for other species and interpreted as the result of their migration from different directions (Nordal and Jonsell 1988; Hewitt 2000). However, in some cases the sample grouping was not always consistent with the region affiliation. Especially, the regions from the southern Europe were overlapping on the plane of the discriminant analysis (Fig. 3). The great differentiation of the Balkan samples can be explained by the dependence of the characters values on altitude: three of the Balkan samples, collected in lower elevation: StPla, SuPla, Din2 had bigger leaves, and so the samples clustered together, despite the location in different parts of the Balkans: eastern, central and western, respectively. The other three samples: Ril, Spla and Din2, were collected in the same Balkan parts, but at higher elevation, and their leaves were smaller (Table 1, Fig. 3, App.1). These situation is responsible for the high variation of the Balkan samples. At the same time, the characters of the Balkan samples showed correlation with altitude. It is possible that this relation is also true for the restof the species range and was not evident in the present study only because the elevation of particular samples were similar. The diminishing of vegetative parts of plants with the growing altitude in the mountains were reported previously (Fabbro and Körner 2004).

Morphological analyses showed resemblances of all regions and the samples from the southern part of Europe, what might be explained by the dependence of Dryas octopetala characters on climate, proved in the present study. Still, the closeness of the Eastern Scandinavian sample to this group is surprising and hard to comment on.

The results of the present study were not fully consistent with the results of the biogeographic molecular analyses of the researched species (Fig. 1). Skrede et al. (2006) indicated a very strong resemblance of the Scandinavian population of Dryas to the western-Alpine population: these populations, together with those of the Pyrenees and Abruzzo, formed a group derived from a common source in the Central European tundra. The division into northern and southern part of the range, demonstrated in the present study, is therefore not justified. Ronikier and Cieślak (2012), in his preliminary analysis, described the relationship - being founded on molecular basis - between populations of the Southern and the Eastern Carpathians and the eastern part of the Balkans, which can be confirmed by the present analyses, as well as between the Alps and the Northern and the Western Balkans, which could not be demonstrated (Fig. 1). The present diversification of morphological characters of the Balkan samples did not reflect the east-west gradient described by the author.

Some parallels can be drawn when comparing the present analyses with the geographic differentiation of two other arctic-alpine shrubs Salix herbacea and $S$. reticulata. For all species, the closeness of the Alpine and the Western Carpathian samples was found, although in the case of S. herbacea, also samples from other parts of the Carpathians belonged to this group (Marcysiak 2012 a). Multidimensional grouping of the latter species showed also closeness of the samples from the Pyrenees and to both part of Scandinavia, and in the present results some similarities between the Pyrenean and the Eastern Scandinavian samples can be found. In the case od S. reticulata, the sample fromWestern Scandinavia joined the Western Carpathian-Alpine group, and means of samples from the Eastern Carpathians and Eastern Scandinavia were located on the opposite side of the graph, although not close to each other (Marcysiak 2012b). The distribution of the Dryas samples on the scatterplot (Fig. 3) is quite comparable, and common preferences to the limestone substrate are the proposed explanation for these similarities.

\section{The dependence of Dryas octopetala leaf characters on the climate}

Analyzing the correlation of Dryas octopetala characters with the climatic factors one should remember that these data are generalized for larger areas. Nonetheless, positive relations of some features of the leaf size with spring months minimum temperature can be regarded as typical: Welker et al. (1997) described the increase in leaf biomass in response to warmer conditions; he also pointed to the importance of higher temperatures in spring and autumn on Dryas phenology. It is more difficult to interpret the negative correlation between the rainfall in the summer months and the number of teeth $(t n)$, as well as the characters describing the narrowing at the base of the leaf $(b l w / b w)$ and at the top (blw/aw). The large width of the peak tooth (aw) clearly distinguishes the Western Carpathian samples. A negative correlation between the number of teeth and the rainfall in June and July was already reported for another arctic-alpine subshrub, Salix herbacea (Marcysiak 2012 b). Toothed leaves are usually associated with the cold climate, which has been confirmed in many studies (Greenwood 2005; Royer and Wilf 2006; Royer et al., 2008). In the case of this study, this relationship may be confirmed by the positive correlation between the 
temperature and the leaf area-perimeter ratio (ar/per), indirectly informing about the indentation depth. However, the greater number of teeth occurred in populations from the southern part of the range, so the correlation 'the number of teeth - precipitation' presumably informed about the relationship between the number of teeth and a the geographic location. The ratio of maximum width to the width of the peak tooth $(b l w / a w)$, which had the highest number of correlations with the climate, at the same time clearly differentiated parts of the range (Fig. 3).

\section{Conclusion}

Geographic differentiation of Dryas octopetala leaf morphology reflect the biogeographic divisions of arctic-alpine species. It seems that it is the influence of the environmental and climatic factors, similar or identical for the populations located in one region, decided about the grouping of samples, because the characters differentiating the regions and strongly discriminating populations were mostly dependent on the influence of the climate (Table 2).

\section{Acknowledgements}

I wanted to express my special gratitude for the collection of material to Anna and Michał Ronikier. I am also very grateful to Amelia Lewandowska for the time-consuming measurements.

The collection of materials and the measurements were partly funded by Kazimierz Wielki University in Bydgoszcz.

\section{References}

Abbott R.J., Brochmann C. 2003. History and evolution of the arctic flora: in the footsteps of Eric Hultén. Molecular Ecology 12: 299-313. http:// dx.doi.org/10.1046/j.1365-294X.2003.01731.x

Bazzaz F.A., Chiariello N.R., Coley P.D., Pitelka L.F. 1987. Allocating resources to reproduction and defense.BioSc ience 37: 58-67. http://dx.doi. org/10.2307/1310178

Bennington C.C., Fetcher N., Vavrek M.C., Shaver G.R., Cummings K.J., McGraw J.B. 2012. Home site advantage in two long-lived arctic plant species: results from two 30-year reciprocal transplant studies. Journal of Ecology 100: 841-851. http:// dx.doi.org/10.1111/j.1365-2745.2012.01984.x

Birks H. H. 2008. The Late-Quaternary history of arctic and alpine plants. Plant Ecology and Diversity 1: 135-146. http://dx.doi. org/10.1080/17550870802328652
Birks H.J.B., Willis K.J. 2008. Alpines, trees and refugia in Europe. Plant Ecology and Diversity 1: 147-160. http://dx.doi.org/10.1080/17550870802349146

Boratyński A., Jasińska A.K., Marcysiak K., Mazur M., Romo A.M., Boratyńska K., Sobierajska K., Iszkuło G. 2013. Morphological differentiation supports the genetic pattern of the geographic structure of Juniperus thurifera (Cupressaceae). Plant Systematic and Evolution DOI 10.1007/s00606-013-07607. http://dx.doi.org/10.1007/s00606-013-0760-7

Boratyński A., Marcysiak M., Lewandowska A., Jasińska A., Iszkuło G., Burczyk J. 2008. Differences in leaf morphology between Quercus petraea and Q. robur adult and young individuals. Silva Fennica 42: 115-124. http://dx.doi.org/10.14214/sf.268

Comes H.P., Kadereit J.W. 1998. The effect of Quaternary climatic changes on plant distribution and evolution. Trends in Plant Science 3: 432-438. http:// dx.doi.org/10.1016/S1360-1385(98)01327-2

de Witte L.C., Armbruster G.F.J., Gielly L., Taberlet P., Stöcklin J. 2012. AFLP markers reveal high clonal diversity and extreme longevity in four key arctic-alpine species. Molecular Ecology 21: 1081-1097. http://dx.doi.org/10.1111/j.1365294X.2011.05326.x

Douaihy B., Sobierajska K., Jasińska A.K., Boratyńska K., Ok. T., Romo A., Machon N., Didukh Y., Bou Dagher-Kharrat M., Boratyński A. 2012. Morphological versus molecular markers to describe variability in Juniperus excelsa subsp. excelsa (Cupressaceae). Annals of Botany PLANTS 2012: pls013. http://dx.doi.org/10.1093/aobpla/pls013

Fabbro T., Körner C. 2004. Altitudinal differences in flower traits and reproductive allocation. Flora 199: 70-81. http://dx.doi.org/10.1078/03672530-00128

Greenwood D.R. 2005. Leaf form and the reconstruction of past climates. New Phytologist 166: 355-357. http://dx.doi.org/10.1111/j.14698137.2005.01380.x

Hewitt G.M. 1999. Post-glacial re-colonization of European biota. Biological Journal of the Linnean Society 68: 87-112. http://dx.doi. org/10.1111/j.1095-8312.1999.tb01160.x

Hewitt G.M. 2000. The genetic legacy of the Quaternary ice ages. Nature 405: 907-913. http://dx.doi. org/10.1038/35016000

Hijmans R.J., Cameron S.E., Parra J.L., Jones P.G., Jarvis A., 2005. Very high resolution interpolated climate surfaces for global land areas. International Journal of Climatology 25: 1965-1978. http:// dx.doi.org/10.1002/joc.1276

Jasińska A.K., Boratyńska K., Sobierajska K., Romo A., Ok. T., Bou Dagher-Kharat M., Boratyński A. 2013. Relationships among Cedrus libani, C. brevifolia and C. atlantica as revealed by the morphological and anatomical needle characters. Plant Sys- 
tematics and Evolution 299: 35-48. http://dx.doi. org/10.1007/s00606-012-0700-y

Jones B., Gliddon C. 1999. Reproductive biology and genetic structure in Lloydia serotina. Plant Ecology 141: 151-161. http://dx.doi. org/10.1023/A:1009805401483

Kapralov M.V., Gabrielsen T.M., Sarapultsev I.E., Brochmann C. 2006. Genetic enrichment of the arctic clonal plant Saxifraga cernua at its southern periphery via the alpine sexual Saxifraga sibirica. Molecular Ecology 15: 3401-3411. http://dx.doi. org/10.1111/j.1365-294X.2006.03024.x

Mal T.K., Lovett-Douts J. 2005. Phenotypic plasticity in vegetative and reproductive traits in an invasive weed, Lythrum salicaria (Lythraceae), in response to soil moisture. American Journal of Botany 92: 819-825. http://dx.doi.org/10.3732/ajb.92.5.819

Marcysiak K. 2012a. Variation of leaf shape of Salix herbacea in Europe. Plant Systematics and Evolution 298: 1597-1607. http://dx.doi.org/10.1007/ s00606-012-0662-0

Marcysiak K. 2012b. Diversity of Salix reticulata L. (Salicaceae) leaf traits in Europe and its relation to geographical position. Plant Biosystems 146 suppl.1: 101-111. http://dx.doi.org/10.1080/112 63504.2012.727879

Marcysiak K. 2012c. Calculated characters of leaves are independent on environmental conditions in Salix herbacea (Salicaceae) and Betula nana (Betulaceae). Acta Societatis Botanicorum Poloniae 81: 153-158. http://dx.doi.org/10.5586/ asbp.2012.027

McGraw J.B., Antonovics J. 1983. Experimental ecology of Dryas octopetala ecotypes. 2. A demographic-model Growth, Branching and Fecundity. Journal of Ecology 71: 899-912. http://dx.doi. org $/ 10.2307 / 2259600$

Nordal I., Jonsell B. 1988. A phylogeographic analysis of Viola rupestris: three post-glacial immigration routes into the Nordic area? Botanical Journal of the Linnean Society 128: 105-122.

Philipp M., Siegismund H.R. 2003. What can morphology and isozymes tell us about the history of the Dryas octopetala-integrifolia complex? Molecular Ecology 12: 2231-2242. http://dx.doi. org/10.1046/j.1365-294X.2003.01875.x

Rieley G., Welker J.M., Callaghan T.V., Eglinton G. 1995. Epicuticular waxes of two arctic species: compositional differences in relation to winter snow cover. Phytochemistry 38: 45-52. http://dx. doi.org/10.1016/0031-9422(94)00649-E

Ronikier M. 2011. Biogeography of high-mountain plants in the Carpathians: An emerging phylogeographical perspective. Taxon 60: 373-389.

Ronikier M., Cieślak E. 2012. Northern component to the southern richness: genetic diversity of the arctic-alpine Dryas octopetala at its Balkan range limits. In: Rešetnik I., Bogdanović S., Alegro A. (eds.). International Symposium on "Evolution of Balkan Biodiversity". Book of Abstracts. BalkBioDiv Consortium and Croatian Botanical Society, Zagreb, Croatia.

Royer D.L., McElwain J.C., Adams J.M., Wilf P. 2008. Sensitivity of leaf size and shape to climate within Acer rubrum and Quercus kelloggii. New Phytologist 179: 808-817. http://dx.doi.org/10.1111/j.14698137.2008.02496.x

Royer D.L., Wilf P. 2006. Why do toothed leaves correlate with cold climates? Gas exchange at leaf margins provides new insights into a classical paleotemperature proxy. International Journal of Plant Science 167: 11-18. http://dx.doi. org/10.1086/497995

Šibik J., Petrík A., Kliment J. 2004. Syntaxonomical revision of plant communities with Carex firma and Dryas octopetala (alliance Caricion firmae) in the Western Carpathians. Polish Botanical Journal 49: 181-202.

Skrede I., Eidesen P.B., Portela R.P., Brochman Ch. 2006. Refugia, differentiation and postglacial migration in arctic-alpine Eurasia, exemplified by the mountain avens (Dryas octopetala L.). Molecular Ecology 15: 1827-1840. http://dx.doi. org/10.1111/j.1365-294X.2006.02908.x

Sokal R.R, Rohlf FJ. 2003. Biometry. 3rd edn. W. H. Freeman and Company, New York.

Soulé M.E., Zegers G.P. 1996. Phenetics of natural populations. V. Genetic correlates of phenotypic variation in the Pocket Gopher (Thomomys bottae) in California. Journal of Heredity 87: 341350. http://dx.doi.org/10.1093/oxfordjournals. jhered.a023012

Tabachnik B.G., Fidell L.S. 2007. Using multivariate statistics. 5th edn. 647 California State University, Northridge.

Vasari Y. 1999. The history of Dryas octopetala L. in eastern Fennoscandia. Grana 38: 250-254. http:// dx.doi.org/10.1080/001731300750044636

Vik U., Jørgensen M.H., Kauserud H., Nordal I., Brysting A.K. 2010. Microsatellite markers show decreasing diversity but unchanged level of clonality in Dryas octopetala (Rosaceae) with increasing latitude. American Jounal of Botany 97: 988-997. http://dx.doi.org/10.3732/ajb.0900215

Welker J.M., Molau U., Parsons A.N., Robinson C.H., Wookey P.A. 1997. Responses of Dryas octopetala to ITEX environmental manipulations: a synthesis with circumpolar comparisons. Global Change Biology 3: 61-73. http://dx.doi. org/10.1111/j.1365-2486.1997.gcb143.x

Zając M., Zając A. 2009. The geographical elements of native flora of Poland. Institute of Botany Jagiellonian University, Kraków. 
Appendix 1. Box-whiskers plot of Dryas octopetala measured characters, in samples; point - mean, box - mean \pm standard error, whiskers - mean \pm 1.96 standard error; samples acronyms as in Table 1
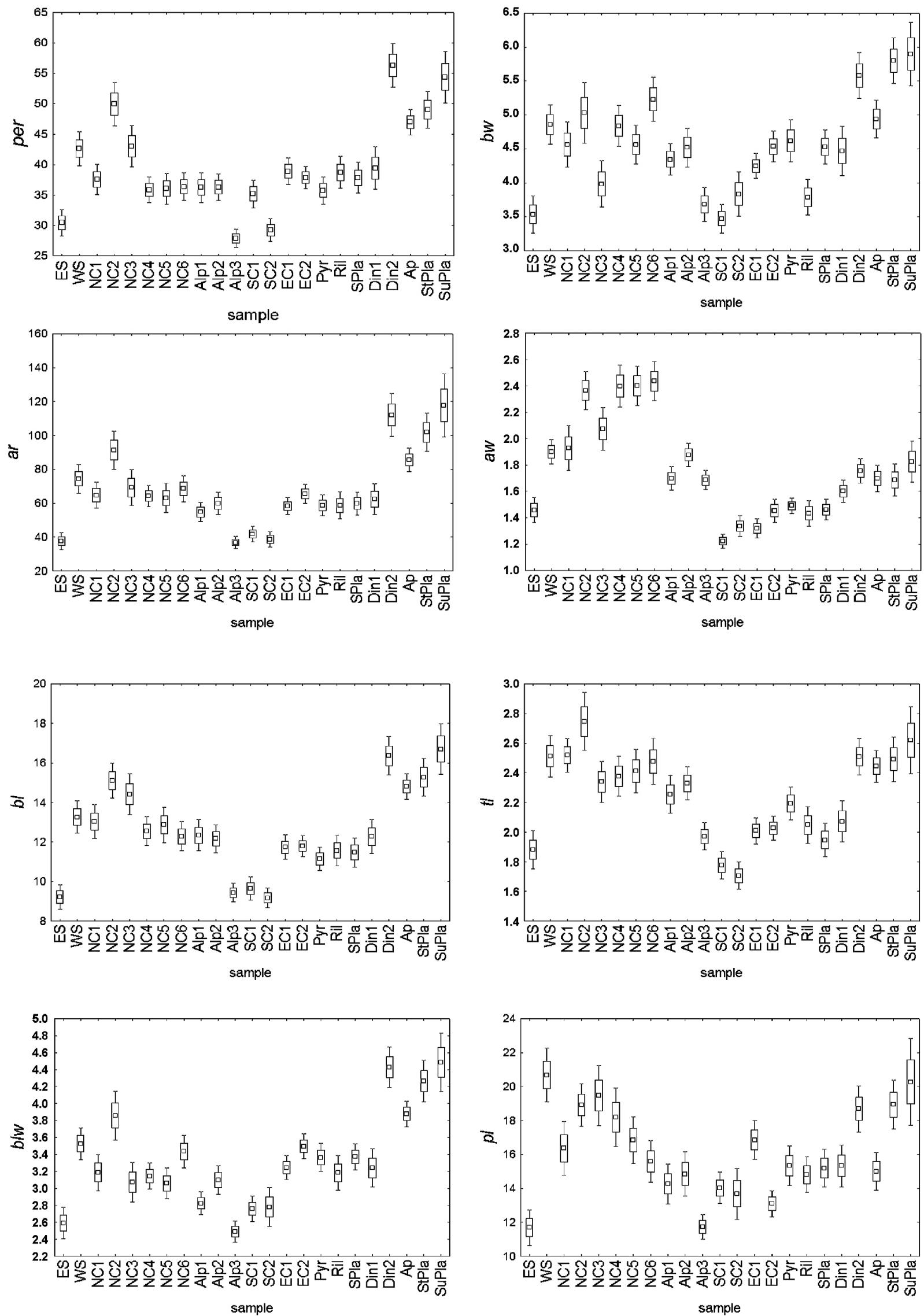
Appendix 2. Box-whiskers plot of Dryas octopetala calculated characters and teeth number (tn), in samples; point - mean, box - mean \pm standard error, whiskers - mean \pm 1.96 standard error; samples acronyms as in Table 1
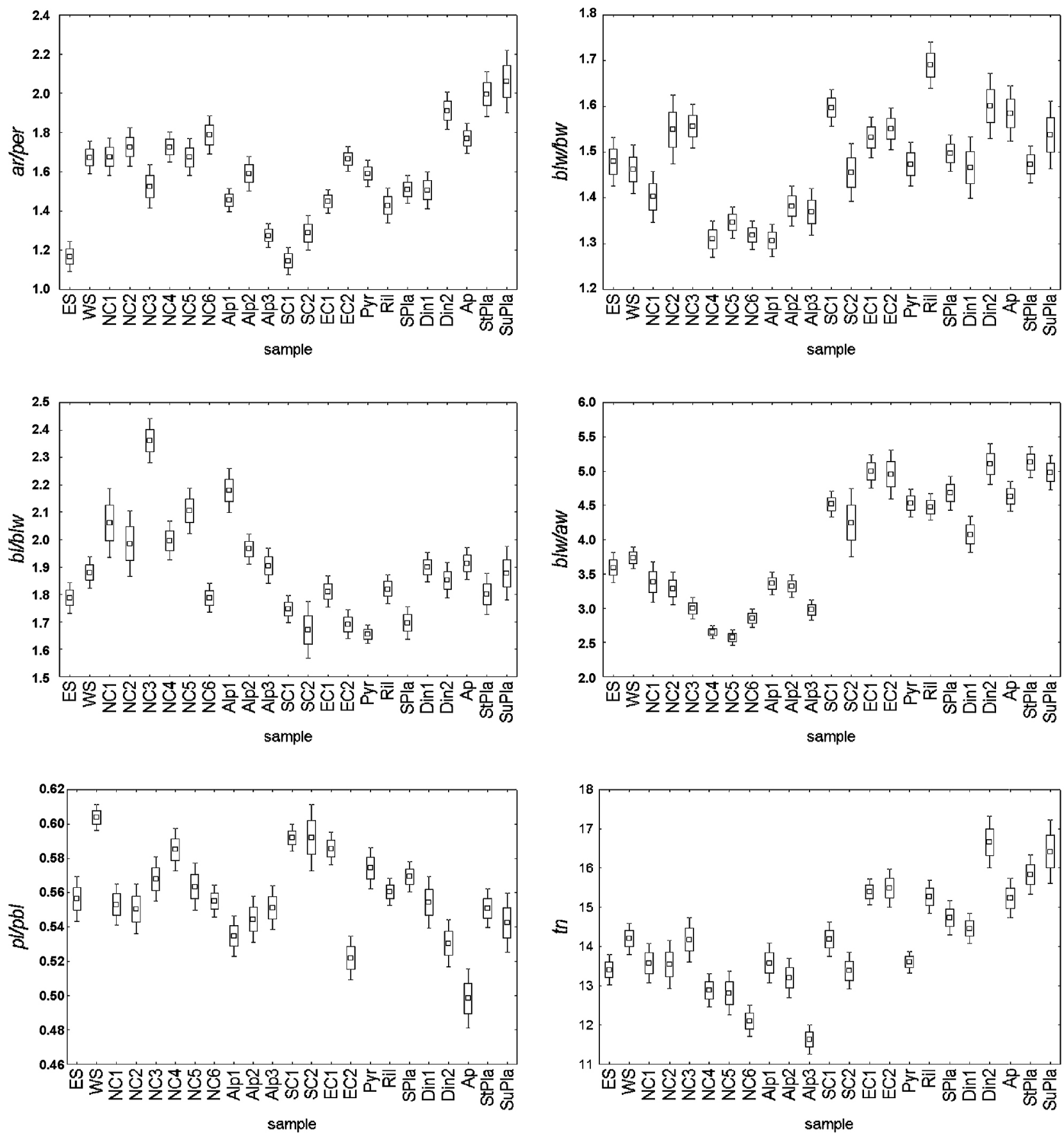